\title{
Incorporating international biodiversity law principles and rights perspective into the European Union Timber Regulation
}

\author{
Claudia Ituarte-Lima ${ }^{1}$ (D) . Amelie Dupraz-Ardiot ${ }^{2} \cdot$ Constance L. McDermott $^{3}$
}

Accepted: 17 April 2019 / Published online: 4 May 2019

(c) The Author(s) 2019

\begin{abstract}
This article assesses the synergies and conflicts between the Convention on Biological Diversity (CBD) and the European Union Timber Regulation (EUTR), and the potential role of the $\mathrm{CBD}$ principles and rights perspective in improving coherence across these diverse forest-related agreements. We find that both the EUTR, which aims to eliminate illegal wood from EU supply chains, and the CBD, with its core focus on biodiversity and healthy ecosystems, share the stated goals of safeguarding biodiversity and local livelihoods. However, the principle of inclusive governance and sustainable use embedded in the CBD conflicts with the EUTR. The EUTR focus on law enforcement asserts the primacy of state laws independently of their sustainability content and alignment with international human rights law. We find that the EUTR risks reinforcing legal frameworks that preference large-scale export production over local forest access, use and benefits. Better aligning the EUTR with CBD safeguards firstly requires opening-up the EUTR rule-making process to broader engagement with affected groups. Secondly, our analysis of both the procedural and substantive dimensions of the EUTR and the CBD safeguards, suggests that opportunities for better alignment lie in the nexus between procedural rights, of which law enforcement forms part of a broader vision of rule of law and conflict resolution, and the strengthening of substantive rights that benefit local forest use and conservation.
\end{abstract}

Keywords European Union Timber Regulation (EUTR) · Convention on Biological Diversity $(\mathrm{CBD}) \cdot$ Legality $\cdot$ Human rights $\cdot$ Safeguards · Environmental law and policy

Claudia Ituarte-Lima

claudia.ituarte@su.se

Amelie Dupraz-Ardiot

amelie.ardiot@bluewin.ch

Constance L. McDermott

constance.mcdermott@ouce.ox.ac.uk

1 Stockholm Resilience Centre, Stockholm University, 10691 Stockholm, Sweden

2 Visiting Researcher, Stockholm Resilience Centre, Stockholm University, 10691 Stockholm, Sweden

3 Environmental Change Institute, University of Oxford, South Parks Road, Oxford OX1 3QY, UK 


\section{Introduction}

EU Regulation No. 995/2010 of the European Parliament and of the Council, commonly known as the EU Timber Regulation (EUTR), forms a core part of the EU's emerging timber legality regime. ${ }^{1}$ The regime's core stated purpose is to promote better governance and sustainable forest management by prohibiting the import of illegal timber, understood as timber harvested in contravention of the applicable legislation in the country of harvest (EC 2010). The EUTR, which entered into force in March 2013, introduces a duty of due diligence for actors placing timber on the EU market for the first time. To fulfill this duty, market actors use procedures and implement risk management-related measures referred to as a "Due Diligence System" (DDS) to minimize the risk of importing illegal timber.

While the core focus of the EUTR is on legality, its legitimacy rests on the presumed link between legality and sustainability, including the protection of biodiversity and local livelihoods. This link is stated either implicitly or explicitly in several related legal and policy documents. For example, the preamble to the Regulation states that illegal logging is driving biodiversity loss and threatening the livelihoods of forest-dependent communities [preamble]. The EUTR also references the broader EU Forest Law, Enforcement, Governance and Trade (FLEGT) Action Plan [2003], which lists biodiversity loss as a core motivation for tackling illegal logging and states a commitment to "promoting equitable and just solutions to the illegal logging problem which do not have an adverse impact on poor people" (EC 2003: 3-4).

If these assertions about the link between legal timber markets, biodiversity and livelihoods are correct, then the EUTR is relevant to a much wider body of international environmental agreements. In regard to biodiversity and markets in particular, the 1993 United Nations Convention on Biological Diversity (CBD), which was ratified by 196 countries, ${ }^{2}$ serves as a key source of international principles and commitments. The CBD has three core objectives: the conservation of biological diversity; the sustainable use of its components; and the fair and equitable sharing of the benefits arising out of the utilization of genetic resources. Mainstreaming Biodiversity into the forestry sector is part of the CBD Strategic Plan 2011-2020, and the Aichi targets agreed by the Parties to the Convention on Biological Diversity (CBD) in $2010 .{ }^{3}$ To meet these objectives, the CBD stresses "the need to enhance coherence, cooperation and synergies among forest-related agreements, and their processes and initiatives, both at the policy and implementation levels... (CBD COP 2016 Decision XIII/7)". Of central relevance to the EUTR, the CBD also provides guidance on safeguards for green timber product markets. These have been articulated in the 12th CBD-COP in 2014 as voluntary guidelines on safeguards in Biodiversity Financing Mechanisms, based on a "rights approach" to markets and finance (CBD Guidelines for safeguards henceforth, CBD 2014a, see also "Appendix"). In 2018, CBD-COP Decision $\mathrm{XIV} / 15$ highlighted the emerging convergence between the CBD Guidelines for safeguards

\footnotetext{
1 The EUTR is also part of what has been portrayed as an emerging global legality verification regime. New legality verification instruments or the amendment of existing ones in various countries outside the EU (Overdevest and Zeitlin 2014) ranges from the USA-amended Lacey Act, to the Japanese Green Purchasing Law and Australian Illegal Logging Prohibition Regulation (Overdevest and Zeitlin 2014; Jonsson et al. 2015).

${ }^{2}$ For more information on the process involved in the development of the CBD voluntary guidelines, see Ituarte-Lima et al. (2018) and Schultz et al. (2018).

3 The Aichi Targets are a set of 20 time-bound, measurable targets under the CBD. Targets especially relevant to forestry and community rights are: Target 7,14 and 18.
} 
and other safeguard processes beyond the $\mathrm{CBD}$, and encouraged all such processes to further refer to the CBD Guidelines in order to create greater convergence (CBD 2018b).

The EUTR and the CBD are distinct in terms of their legal nature, purpose and what they do. Hence, we do not intend to compare them. Instead, our aim is to further the understanding of how, as part of the corpus of international law, these legal instruments interplay. This paper's main objective is to assess whether - and if so, how - the EUTR might better incorporate the CBD's "rights approach," and associated principles, guidance and safeguards (henceforth CBD principles) for forest products markets.

\section{Theoretical framework and methods}

The fragmentation of international law has generated a rich literature that attempts to conceptualize and/or bridge such fragmentation (see Brown Weiss 1993; Wolfrum and Matz 2003; Doelle 2004; van Asselt et al. 2008; Carlarne 2008; Biermann et al. 2009; Scott 2011; Anton 2012). One example is the conceptualization of Transnational Environmental Law, which adopts a broad understanding of contemporary legal systems that includes not only state-based legal frameworks, but also other state and non-state, and binding and nonbinding, institutional arrangements (Etty et al. 2013).

Different international legal regimes overlap within the forest sector, creating specific challenges for navigating the fragmentation of international law (see, e.g., van Asselt 2012). By legal fragmentation, we mean on the one hand an increased thematic specialization, for example, in regulation specifically addressing forests, and on the other hand diversification in international governance arrangements, where many regulations may have a bearing in a specific situation (van Asselt 2011). Implications of legal fragmentation are not always apparent and may include conflicts between norms. Yet, fragmentation can also open legal spaces for synergies even when possibilities for mutual support are not stated as part of the respective international agreement. Hence, this concept of legal fragmentation acknowledges both challenges and opportunities. Beyond the academic literature, the need to find synergies between distinct treaties and strategies, such as between the CBD and the UN strategic plan for forests 2017-2030, has also been acknowledged in the international environmental arena, including by CBD-COP Decisions (e.g., see CBD 2014b, 2018a, c).

While there has been considerable research on the interactions between public mandatory regimes and market-based initiatives, our research focus is distinct. Rather than analyzing broader regime interactions (see, e.g., Scott 2011) or the specific relationships between timber legality and certification (see, e.g., Bartley 2014), we focus on the intersection of EUTR provisions with the CBD principles relevant for rights approaches and safeguards in markets for forest products.

Current international law and policy already embeds certain safeguards relevant for navigating the interplay of international legal instruments relevant to timber products, protection of biodiversity and indigenous peoples and local communities'(IPLCs) rights. It is also a dynamic arena with new guidance emerging in other biodiversity-related conventions, such as the Convention on International Trade in Endangered Species of Wild Fauna and Flora (CITES) and the UN Framework Convention on Climate Change (UNFCCC). For example, guidance for making legal acquisition findings, expected to be adopted at CITESCOP 18 in 2019, intends to bridge the gap between legal protection status for CITES-listed 
species such as the wild African rosewood ${ }^{4}$ and consistent implementation of the safeguard for legal acquisition across CITES Parties. ${ }^{5}$

Literature has emerged on safeguards in Reducing Emissions from Deforestation and Degradation and forest enhancement (REDD+) under the UNFCCC (Voigt 2016; Lyster et al. 2013). For example, there have been studies on the nexus of REDD+ with international human rights law that assess whether REDD+ social safeguards generate obligations for state and non-state actors to protect human rights (Savaresi 2013, 2016). Research on REDD+ has also examined the legal aspects of safeguarding natural forests and biodiversity (Bodin et al. 2015) and the legal implications of REDD+ "result-based payments," i.e., payments to countries for reducing forest emissions (Voigt and Ferreira 2015).

In contrast to the scholarly attention to REDD+ safeguards under the UNFCC, little attention has been given to the interface between forest governance and the CBD guidance on safeguards. Yet the CBD contains a wealth of guidance for forest governance, ranging from the general to the specific. This includes, for example: (1) the Akwe: Kon voluntary guidelines for the conduct of cultural, environmental and social impact assessments regarding developments proposed to take place on, or which are likely to impact on, sacred sites and on lands and waters traditionally occupied or used by indigenous and local communities (CBD Akwé: Kon guidelines) (CBD 2008), (2) the CBD Addis Ababa principles and guidelines for the sustainable use of biodiversity (CBD Addis Ababa Principles) (CBD 2008) and (3) the more explicit principles embedded in the CBD Guidelines for safeguards (CBD 2014a, b). All of this guidance is relevant to the EUTR; there has been a dearth of research addressing how the EUTR might safeguard biodiversity and local communities' human rights.

In order to better understand how the EUTR has emerged, and what it does, it is important to view the EUTR as part of a broader "legality movement" within the forest sector and to interrogate how this movement is shaping the definition of legality. The legality movement raises a host of issues around who has the right, or even the responsibility, to ensure that international agreements produce desired environmental and social outcomes. The movement has been heralded as a breakthrough because it by-passed struggles over sovereignty, and disputes over the right of countries to use their forests as they chose (Humphreys 2008). It did so by embracing the law and law enforcement as the appropriate building blocks for achieving "good" governance (EC 2010). Yet a definition of legality that a priori embraces existing laws risks overlooking the political contexts within which these laws are created, as well as how requirements to verify legality may themselves prefer certain actors, or laws, over others. Examining the impacts of the legality definition subsumed in the EUTR is particularly significant for the many developing countries where the legal framework promoting industrial timber extraction or the expansion of commercial agriculture may override protections for biodiversity, and where the majority of rural poor lack clear tenure or rights of forest access. ${ }^{6}$ In such a context, there is a distinct risk that

\footnotetext{
4 At CITES-COP 18, Agenda item 74 will address the issue of rosewood timber species which is particularly relevant considering the illegal trade of this species from West Africa to China (CITES 2019a). On this topic, see also Environmental Investigation Agency (2017).

5 See CITES-COP 18 Agenda item 39 "Guidance for making legal acquisition findings" at https://cites.org/ eng/cop/18/doc/index.php (CITES 2019b).

6 For example, through case studies in Honduras and Senegal, Larson and Ribot (2007) show how in spite of reforms since the end of the colonial period, forest policies often remain biased against rural communities and even when more recent policies are relatively fairer, the rural poor face severe biases in the implementation and must compete on an uneven playing field of social and economic inequities.
} 
instruments like the EUTR that demand legality verification to access lucrative markets, could further bias both the making of laws and their enforcement in favor of more powerful actors.

The following analysis of the EUTR therefore begins by considering which actors were involved in designing the EUTR as a governance instrument, and within what context. We call this initial framing process "parameter-setting," in line with McDermott et al. (2013), who note the importance of such foundational decisions in shaping who is included and excluded in environmental governance. This parameter-setting occurs not only through the deliberate agency of the state actors shaping the EUTR system, but also through the nature and structure of the international markets within which the EUTR operates.

Within this larger context of parameter-setting, we then draw on the legal distinction between substantive and procedural in human rights law (see, e.g., Knox 2017; ItuarteLima et al. 2018; Ebbesson and Hey 2013; Shelton 1991). We argue that substantive and procedural law can be an entry point for assessing the interplay between the CBD and the EUTR, and for better incorporating the CBD principles into the EUTR. Procedural law refers to the processes and means for making effective and enforcing rights and duties, such as the right to information, public participation and access to justice in environmental matters. ${ }^{7}$ Procedural law is intertwined with substantive law, which defines the rights and duties related to socio-ecological systems that affect human livelihoods such as the right to an adequate environment, right to life, right to health and property/tenure rights. ${ }^{8}$

As Hey (2015), Ebbesson and Hey (2013), and Shelton (1991), we view substantive and procedural rights as inherently interlinked. Moreover, tensions and possible synergies between substantive and procedural rights may emerge. Shelton (1991) notes that procedural guarantees of information and political participation, which have been interpreted and extended specifically to cover environmental decisions, can only effectively protect the environment if coupled with substantive regulation. Ebbesson and Hey (2013) consider that while aiming to foster socio-ecological resilience, equality before the law and nondiscrimination should be fostered, among other things, through public participation.

This study is based on a literature review, analysis of the EUTR, CBD-COP Decisions and other written material by various stakeholders, including opinions expressed by experts in the specialized press. The analysis of parameter-setting, in particular, draws on evidence of the ways in which legality initiatives are impacting the relative power of different stakeholders both inside and outside of the EU.

\section{Parameter-setting: the governance of the EUTR}

The EU Timber Regulation (Regulation 995/2010) was enacted by the EU as a means to address controversies over the external impacts of EU timber consumption on exporting countries. It emerged as one among a number of measures spawned by the EU's 2003 Forest Law Enforcement Governance and Trade (FLEGT) Action Plan. FLEGT constituted a major shift in international forest politics. Specifically, it moved away from a core focus on

\footnotetext{
7 See examples of procedural environmental rights in Anton and Shelton (2006).

8 See more on substantive environmental rights in e.g. Bruch et al. (2001). For example, tenure rights constitute legally relevant relationships, defined by formal laws or customarily, among peoples as individuals or groups to determine who can use which natural resources and under which conditions. See Ciparisse (2003: 36) and Ghezae et al. (2009).
} 
sustainability, to one primarily focused on legality—a shift which carried significant implications for how the parameters for rule-making were set.

Throughout much of the 1990s and early 2000s, the EU had been a strong proponent for the creation of a multilateral, legally binding international forest convention, which it was hoped would produce a common set of goals and targets for sustainable forest management worldwide (Humphreys 2008). However, certain countries opposed such an agreement arguing that it would affect their sovereign right to pursue their own forest priorities (ibid). A subsequent shift in international focus from sustainability to "legality" promised a way around this debate, by appearing to bypass the need for common agreement on sustainability and focusing on law enforcement. The apparent neutrality regarding definitions of sustainability, and the content of a country's laws, ${ }^{9}$ also opened the door for unilateral government actions restricting trade in "illegal" products. It was this neutrality that enabled the EU to impose such restrictions without violating the rules of the World Trade Organization (WTO) which strictly prohibit unilaterally imposed sustainability standards for product imports (Geraets and Natens 2015).

The new focus on legality spurred a number of studies, highlighting how a large percentage of logging in developing countries was "illegal." For example, a Chatham House study found that illegal logging accounted for as much as 35-72\% of timber harvesting in the Brazilian Amazon, 22-35\% in Cameroon, 59-65\% in Ghana, 40-61\% in Indonesia and $14-25 \%$ in Malaysia (Lawson and MacFaul 2010). This illegal activity is attributed primarily to governance problems related to a lack of resources and capacities and/or to an imprecise or inappropriate legislative framework, e.g., in case of conflict with customary rules. ${ }^{10}$ In fact, and as clearly stated in the EU Timber Action Plan itself (EC 2003), these conditions are typical of forest production across much of the developing world, where forest tenure and use rights are unclear, forestry laws are highly complex and restrictive, and many communities lack legal recognition of their customary laws and tenure arrangements (McDermott et al. 2010).

Evidence suggests that a significant portion of the timber classified as "illegal" is produced for domestic and local consumption and is governed by customary laws not recognized by the state (McDermott et al. 2019). Such customary laws are what have enabled significant numbers of local women, men and youth to engage in sustainable forest use and conservation, even in the absence of secure tenure rights to forest resources (ItuarteLima and McDermott 2017). As international focus shifted from sustainability to legality, this effectively de-legitimized such actors in favor of any and all forms of legal, industrial production.

The EUTR was first envisaged as one of two complementary actions proposed in the 2003 EU FLEGT Action Plan. The first initiative was the creation of bilateral partnerships with developing country trade partners, now known as Voluntary Partnership Agreements (VPAs). Countries that chose to enter these agreements would work with the EU to improve and streamline their forest laws, develop a common definition of "legal wood" and create a system of legality licensing for wood-entering EU markets. In other words, the setting of parameters of acceptable trade with the EU was achieved bilaterally, between governments. In addition, the EU also required that VPA partner countries develop participatory

\footnotetext{
${ }^{9}$ Larson and Ribot (2007), who argue that the so-called neutral policies overlook existing inequalities rooted in class identity, economic or social relations and these issues need to be addressed if laws and policies are to enable local people to access forest resources and markets.

10 http://www.illegal-logging.info/topics/causes, accessed 3th January 2016.
} 
processes to gain wider stakeholder acceptance (EC 2003). Once the VPA was agreed, and a system of legality licensing in place, only legally licensed timber from their VPA partner country would be allowed to enter the EU. Distinct actors interpret legality in FLEGT and VPA in different ways: while some advocate a narrow interpretation of legality that focuses on law enforcement, others advocate a broader interpretation that includes issues of participation and sustainability (van Heeswijk and Turnhout 2013) in line with the human rights-based perspective. Turning law enforcement into an end risks neglecting sustainability issues (ibid).

The EUTR came into force in March 2013 as a means to complement the VPA process, and they were developed to reinforce each other (Jonsson et al. 2015). The EUTR was a unilateral initiative with parameters determined solely by the EU, and these parameters were set in large part through the defined scope of products covered, the EUTR definition of legality, and the requirements set forth for EU member countries. The EUTR is complemented by the regulation 363/2012 laying down the rules for the recognition of monitoring organizations by the Commission, and by the regulation 607/2012 providing detailed rules for due diligence systems and for the checks of monitoring organizations by Competent Authorities.

The EUTR regulates a large range of wood products: solid wood and wood chips, secondary processed wood products such as many items of furniture, and pulp and paper but also includes a substantial list of exceptions. ${ }^{11}$ Illegally harvested timber refers to wood harvested in contravention of the applicable legislation in the country of harvest; applicable legislation refers to specific regulations setting the zone and fees to harvest and to more overarching laws on forest management and biodiversity conservation (Art. 2, let. H, EUTR).

However, as is common in legal implementation, there is still much that is undetermined regarding precisely what is, or isn't considered legal. To date, government corruption in the awarding of licenses has not been considered within the scope of the EUTR. For example, the Indonesia and Ghana VPAs do not include the process of obtaining a license in the legality definition (Lesniewska and McDermott 2014), and timber licensed to comply with these VPAs is automatically considered EUTR compliant (McDermott et al. 2019). The EUTR final guidance document, ${ }^{12}$ which is an authoritative interpretation of the EUTR, refers only a country's overall level of corruption as an indicator of the reliability of its legal documents, but nowhere does it state responsibility to investigate government licensing procedures.

The implementation of the EUTR is the responsibility of EU Member States. Each member state must designate a Competent Authority for the enforcement of the EUTR and for laying out penalties. (Hence penalties differ from country to country.) Within each state, there are two categories of actors liable for complying with the EUTR, each having different duties: operators and traders. Operators are companies or persons placing timber on the EU internal market for the first time. Traders are companies or persons selling or buying timber, that has already been placed on the European market by operators.

While both of these actors have obligations derived from the EUTR, it is the operators who must establish a Due Diligence System (DDS) that involves regular assessments to ensure that they do not trade illegal timber (Art. 4). Operators may establish their own

\footnotetext{
11 See: http://www.nepcon.net/eutr-which-products-are-covered, accessed 3th January 2016.

12 EUTR guidance document, September 2013. http://ec.europa.eu/environment/forests/pdf/Final\%20Gui dance\%20document.pdf, accessed 3th January 2016.
} 
DDS or use the one provided to them by a third party, called a "monitoring organization" (MO). MOs are another key actor in the governance of the DDS who may provide operators with a DDS, verify the proper use of it and, in case of failure by an operator, report to the Competent Authorities. Organizations wanting to be MO have to be recognized by the EU Commission. Competent Authorities (CAs) are expected to regularly check operators against fulfillment of their duties and against compliance of their DDS with the requirements of the EUTR. Competent Authorities are also in charge of checking MOs. The EU Commission may withdraw recognition on the basis of the results of the checks performed by the Competent Authorities.

The governance of a DDS may include institutions such as certification and third-party verification schemes like Forest Stewardship Council or Programme for the Endorsement of Forest Certification. However, these schemes alone are not considered as sufficient to guarantee compliance with the EUTR, in part because the precise scope of their legality requirements is distinct from those of the EUTR. ${ }^{13}$

The EUTR guidance document mentioned earlier is intended to be regularly reviewed according to the issues raised by concerned stakeholders and Member States. This provides an avenue for ongoing non-state participation in the development of EU guidance. However, the document is not legally binding and does not refer specifically to biodiversity and IPLCs' rights. Hence, further information would be needed in order to assess whether operators are fulfilling their duties and complying with their respective DDS under the EUTR and safeguard-related commitments on biodiversity and IPLCs' rights.

In sum, this section has examined parameter-setting as it has unfolded in EUTR governance. At the most fundamental level, the EUTR is a unilateral action taken collectively by its Member States, which asserts the primacy of state law and state regulation in all countries. This includes many countries where state governance is known to be weak, and where local communities lack formal legal access to forest resources and derive significant benefits from informal, i.e., "illegal" activities.

The question remains, however, whether and how the EUTR's trade-based incentives might influence non-EU governments to reform their legal frameworks over time. Yet given that local stakeholders in producing countries are excluded from setting the parameters of the EUTR, and that the EUTR's incentives are focused exclusively on legality assurance for international trade, the EUTR would appear to offer little incentive to change laws in support of low capacity, disadvantaged stakeholders and forest producers. Furthermore, the more exacting and difficult the EUTR requirements for proving legality, the greater the likelihood that only a few producers will have the state support and capacity to do so.

In this article, we do not propose that all of the potential impacts of the EUTR on biodiversity and livelihoods must be addressed through EUTR legislation. Other FLEGT instruments such as the VPAs and related initiatives such as the FAO-FLEGT Programme ${ }^{14}$ may play a role in addressing them. Instead, we argue that it is important to question and evaluate the EUTR for impacts on biodiversity and on small-scale timber enterprises and forestdependent people in developing countries. This assessment will better position the EU to

\footnotetext{
13 http://www.nepcon.net/newsroom/eu-timber-regulation-will-fsc-and-pefc-pass-mark, accessed 3th January 2016.

${ }^{14}$ The FAO-FLEGT Programme, supports the European Union to implement FLEGT; it identifies both illegal logging and weak forest governance as key contributing factors to climate change and biodiversity loss. http://www.fao.org/3/a-i5872e.pdf, accessed 4th August 2017.
} 
achieve its broader goals, and its Member State commitments under international agreements such as the CBD.

\section{Assessing safeguard-related provisions under the EUTR, and the incorporation of CBD principles}

The analysis above has served to assess how the parameters of the EUTR have been set, including who has decided what wood is tradable within the EUTR system and what is, or isn't, encompassed by the EUTR (i.e., the definition of illegally logged wood covered by the EUTR and scope of the legality definition). This section now focuses on the resulting content of the EUTR and its nexus with the CBD safeguards. In particular, we examine what specific safeguard-related provisions are currently included in the EUTR.

Our analysis, summarized in Table 1, considers each of the four themes articulated in the CBD safeguard guidelines (see "Appendix"), and how the EUTR does, or does not, address them through its substantive and procedural content. We refer to substantive safeguards as those measures relevant for the definition of rights and duties related to biodiversity and livelihoods including those of IPLCs (the "what"), whereas procedural safeguards refer to the process for making effective these rights and duties (the "how"). For example, the EUTR DDS can be seen as a procedural measure in order to achieve the substantive dimensions of the EUTR including those relevant to biodiversity and IPLCs' rights.

Existing EUTR safeguard-related provisions concerning roles of Competent Authorities, monitoring organizations and the EU Commission can be used as an entry point for incorporating the CBD principles of multilevel governance within the EUTR. For example, the CBD guideline for safeguards (c) refers to country-driven, specific processes that take into account relevant international agreements such as existing EUTR provisions. The CBD Addis Abba principles propose governments to encourage sustainable use to maintain habitats and ecosystems, the species within them, and the genetic variability of the species places. It is framed as an incentive to do so where risks of converting natural landscapes to other purposes are high. The EUTR existing reference to risk mitigation and the Due Diligence System can be woven into this type of guidance.

\subsection{Procedural law}

The main procedural dimension of the EUTR is the Due Diligence System (DDS), whose mandatory elements are described in Article 6 (see "Appendix").

Only two points in Article 6 address biodiversity-related issues: the necessity of gathering the names of the tree species placed on the inner market (Art. 6a) and of assessing risk on the basis of the prevalence of illegal harvesting of specific tree species (Art. 6b). However, some other elements mentioned in Article 6 may be relevant for safeguarding biodiversity and IPLCs' rights through the provision of relevant information. Such elements are:

- Information on the country of harvest, information on the concession, and the quantity of wood product traded (Art. 6a, as well as Art. 3 of Regulation 607/2012

- Documents indicating compliance with applicable legislation (Art. 6a).

- Assurance of compliance with applicable legislation, which may include third-party verification or certification schemes (e.g., FSC or PEFC) (Art. 6b).

- Prevalence of illegal harvesting in the country of harvest (Art. 6b). 


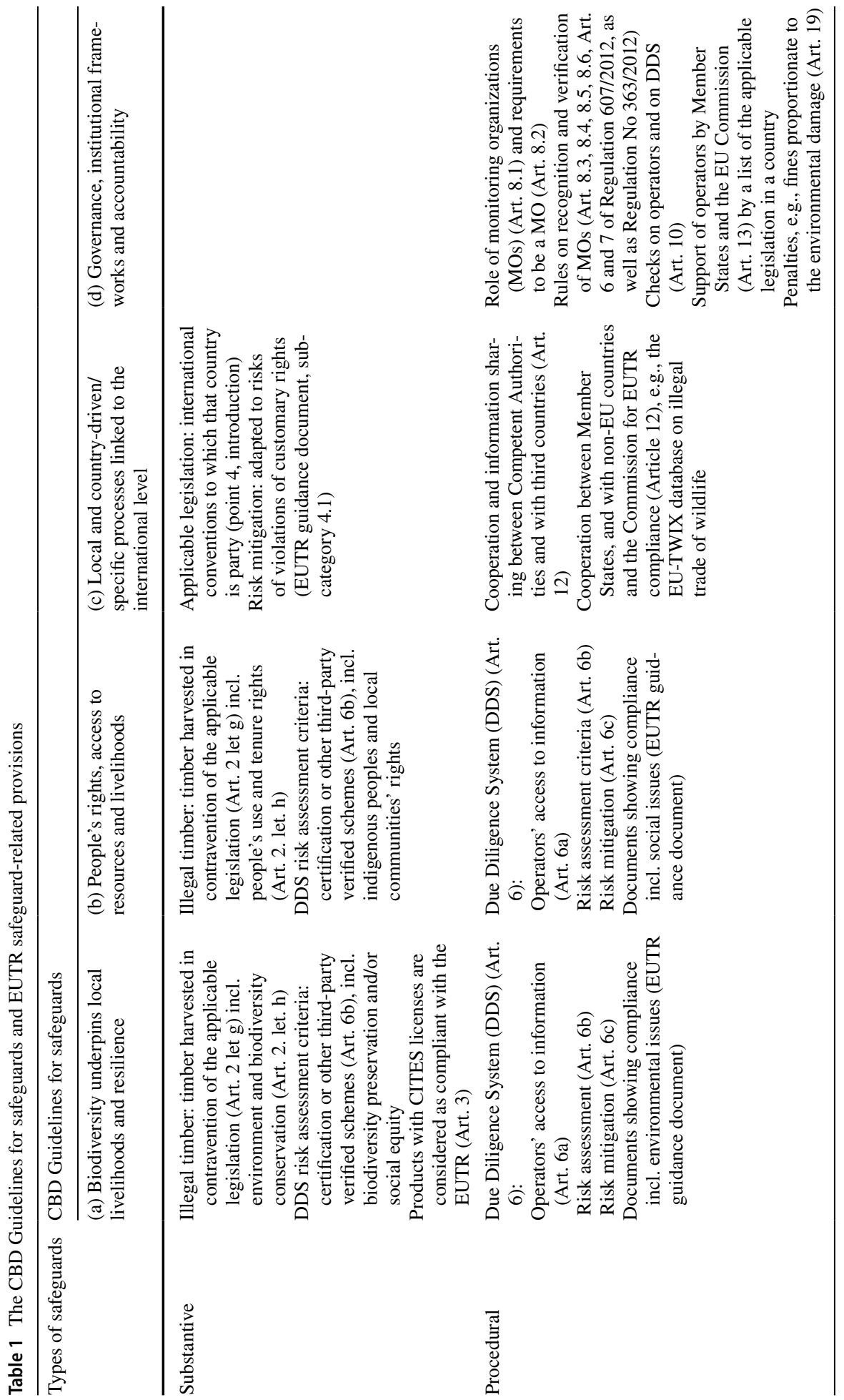


The measures included in the risk mitigation process as described in Art. 6c (gathering of further information, third-party verification) could also be considered as relevant if they address the reduction of environmental and social risks (although such types of risks are not explicitly mentioned under Article 6c). Furthermore, the EUTR guidance document ${ }^{15}$ provides examples of documents showing compliance with the applicable legislation, some of them being explicitly related to environmental and social issues (e.g., codes of conducts, environmental audit reports, specific reports on tenure and rights claims and conflicts).

Defining the roles and duties of the public and private actors involved in the enforcement of the EUTR (Competent Authorities, monitoring organization, EU Commission), the rules regarding the publication of information, the adoption of complementary legislation and rules for setting specific penalties are all EUTR procedural dimensions. However, these prescriptions are not directly related to biodiversity or social issues. Only if priority is placed on legal protections for biodiversity and local welfare, might the EUTR contribute indirectly to safeguarding healthy ecosystems or community rights.

According to Article 13, Member States may provide operators with support to facilitate their compliance with the EUTR. The EUTR guidance document mentions that such assistance may consist in supporting operators by searching which legislation is applicable in a particular country. Providing that type of support, as long as it includes information on the legislation related to biodiversity and IPLCs' rights, should be regarded as relevant for procedural safeguards related to biodiversity and third parties' rights.

\subsection{Substantive law}

According to Art. 2, let. G of the EUTR, illegal timber refers to timber harvested in contravention to the applicable legislation in the country of harvest. The legislation considered includes legal rights to harvest timber within set boundaries, payment for harvest rights, environment and biodiversity legislation related to timber harvesting, third parties' rights of use and tenure, and trade and customs (Art. 2. Let. h). The degree to which the verification of compliance with this legislation will protect biodiversity and local forest user rights depends on the adequacy of existing, state-recognized tenure systems as well as on the content of national and subnational legislation of the country of harvest.

As mentioned earlier, operators may include third parties' certification or verification schemes in their DDS (Art. 6b). Many of these schemes address both biodiversity and social concerns, like FSC third core principle ("to identify and uphold indigenous peoples' rights of ownership and use of land and resources") and sixth core principle ("to maintain or restore the ecosystem, its biodiversity, resources and landscapes"). The substantive priorities of certification schemes vary significantly, and hence also their degree of convergence with the guidelines put forward by the CBD Guidelines. For instance, schemes such as Fair Trade or Social Accountability International prioritize social benefits, although they may also include certain environmental standards. In contrast, other certification schemes may enforce prescriptive standards for biodiversity conservation but have relatively few and/or flexible standards on social equity. ${ }^{16}$ Therefore, the consideration of such schemes

\footnotetext{
15 http://ec.europa.eu/environment/forests/pdf/Final\%20Guidance\%20document.pdf, accessed 3th January 2016.

16 See various certification schemes at http://www.ecolabelindex.com.
} 
can contribute to safeguard biodiversity and IPLCs' rights associated with them to the extent to which the schemes effectively address these concerns.

As mentioned above, FLEGT licenses from VPA countries are also accepted as proof of legality under the EUTR. In 2016, Indonesia became the first country to have had its FLEGT licensing system approved (McDermott et al. 2019). These FLEGT licenses are based on the SVLK, Indonesia's national legality licensing system. When the VPA was signed in 2013, SVLK required all forest operators and processors to obtain private, thirdparty verification of legality, including smallholders and community forest owners and the estimated tens of thousands of small-scale wood handicraft and timber businesses distributed across the Indonesian archipelago (Obidzinski et al. 2014). Concern that the SVLK would exclude small enterprises from legal markets led to subsequent revisions that allowed self-declarations of legality in certain limited cases. This created conflict with the EU, which was not prepared to accept self-verification as proof of legality for FLEGTlicensed timber (Setyowati and McDermott 2017). Such struggles illustrate a tension between stringent verification requirements and local benefit and access to forest resources.

\subsection{Intertwining substantive and procedural rights}

Substantive and procedural rights are interconnected. States have substantive obligations to adopt laws that effectively protect against harm to forest biodiversity that affects the enjoyment of rights. The effectiveness of these laws often depends on procedural law, such as participation in forest decision making and access to dispute resolution. Harm to forest biodiversity and ecosystem services that forests provide can sometimes have disastrous consequences for indigenous peoples, forest-dwellers and other people who rely directly on the forest products for their food, fuel and medicine (Knox 2017). This is not only because of their direct connection with forests, but also because they often have little economic and political power within their countries, and hence have limited or no access to decisionmaking processes or legal remedies. Furthermore, and as noted above, their legal rights to the territory and resources on which they have historically lived and depend may not even be recognized by their respective governments (ibid).

Furthering the nexus between procedural and substantive aspects embedded in CBD principles can be a means to complement areas not explicitly covered by the EUTR but that are relevant to address EUTR impacts, including the rights of IPLCs. This could help address local priorities and further the rights perspective, which is a key element of the CBD Guidelines on safeguards including guideline (c) which calls for safeguards to be grounded in local circumstances and take into account international human rights treaties. Likewise, the CBD Addis Ababa principles also concern substantive local priorities and this instrument connects them to procedural dimensions such as the importance of the capacities of governments. These principles recognize the need for a governing framework in which users of biodiversity are sufficiently empowered and supported by rights. They also make reference to substantive aspects such as fostering the sustainable use of biodiversity to safeguard the livelihoods of the millions of people substantially dependent on harvested plants and animals; and calling for appropriate policies that account for indigenous and local communities' livelihoods and cultures, who often depend directly on the uses of biodiversity. The Akwe: Kon Guidelines have an emphasis on procedural aspects that go beyond legality, addressing how to assess impacts, mechanisms for public participation, management and monitoring plans, review and appeal processes. These Akwe: Kon Guidelines also link to procedural law with substantive law such as highlighting the values 
of sacred sites and forested lands occupied or used by indigenous peoples or local communities, gender, generational, health and social cohesion considerations. The nexus between procedural and substantive made in the Akwe: Kon Guidelines can serve for better incorporating the CBD principles into the EUTR specifically to evaluate more holistically the impacts of legal enforcement on these types of sites and forest lands.

\section{Discussion and concluding remarks}

The purpose of incorporating the CBD principles and the rights-based approach into the EUTR is not only to prevent possible negative impacts, but also to positively promote the development of laws and regulations that support healthy and diverse forest ecosystems and thriving human communities. In the last CBD-COP, Parties adopted a Decision on an inclusive and participatory preparation process for the post-2020 global biodiversity framework. While this process aims to ensure the coherence and complementarity with other existing or upcoming international forest-related processes, it also aims to build and recognize the contribution of IPLCs, women, youth and other groups to this process (CBD 2018a). Incorporating biodiversity principles and rights-based approach can help us shift from a focus on legality to a focus on legally empowering local forest producers to exercise their human right to a healthy environment, protecting and sustainably using forest diversity.

This paper evaluated the EUTR's current and potential role in fulfilling this vision. This began with a consideration of EUTR "parameter-setting," i.e., who has been included and excluded in setting the parameters of what the EUTR aims to achieve and how. At the most basic level, the EUTR is a unilateral policy for regulating the EU's international forest trade. Its nature as a unilateral instrument has enabled the EU to act on its own authority to set the boundaries for the definition of legality and decide on the types of imported wood products to which the definition applies, as well as to set the requirements for member states, timber operators and traders to demonstrate legality.

This focus on legality, by its very nature, privileges the role of state authority. While it is known that state authority in many exporting countries is not exercised in a participatory or inclusive manner, the question remains if there are mechanisms by which the EU's demand for legal timber might motivate changes in state laws in the future. Our above analysis suggests that a stringent and narrow interpretation of legality in the EUTR implementation could serve to further criminalize local forest users in many countries and increase consolidation of the international timber industry, if it is not accompanied by proactive legal reforms that ensure smallholder and local access to affordable and legal timber and forest tenure rights vital for local livelihoods. More open debate is needed that gives these forest stakeholders more voice in EUTR decisions that affect them, if the EUTR is to better align with the CBD principles.

Our analysis of parameter-setting suggests that the EUTR is unlikely to incorporate the CBD principles merely by reinforcing existing state laws. Indeed, the more stringent the legality verification requirements, the more likely it is to further undermine local peoples' access to forest resources and squeeze out disadvantaged producers and producing countries in favor of large-scale, high-capacity firms. From this perspective, participation and capacity-building would appear favorable for incorporating CBD principles into the EUTR, with increased emphasis on rewarding collaboration between EU traders and their trading partners, particularly in regard to safeguarding biodiversity and community rights. Furthermore, in order to 
avoid the EUTR simply diverting trade away from disadvantaged producers and countries, allowances could be made for "step-wise" efforts to continually improve performance over time. However, legal actions against operators, traders and/or Member States could still remain a favored option for the more egregious and willful cases of illegality, with penalties linked not only to the degree of due diligence, but also to the degree of harm.

Complementary to the analysis of the parameter-setting of the EUTR, we have also examined what specific safeguard-related provisions are already embedded in the EUTR which can help identifying legal spaces for synergies between the EUTR and the CBD, even when mutual supportiveness possibilities are not stated as part of the respective agreements. Provisions in the EUTR which we found relevant for safeguards include Article 2, which refers to compliance with forest tenure rights and with laws governing biodiversity, as well as Article 6 , which although it is mainly concerned with procedures, also mentions third-party certification schemes that address biodiversity and indigenous and local community rights. A political decision acknowledging the importance of, and increasing the resources allotted to, safeguardrelated issues within the DDS under the EUTR could help incorporate CBD principles into the EUTR.

The final entry point for incorporating the CBD principles and guidelines into the EUTR lies at the nexus between substantive and procedural law. Consistent with Knox and Boyd (2018), Ebbesson and Hey (2013) and Shelton (1991), we find that both substantive and procedural legal dimensions are necessary and neither alone is sufficient. Whatever importance is given to the procedural aspects of the EUTR, these only safeguard substantive biodiversity or/and social rights as long as such rights are legally recognized and effective mechanisms exist to exercise them. The CBD principles provide an overarching framework for assessing how existing laws - and by implication their enforcement through the EUTR - do, or do not, safeguard biodiversity and local welfare, and call for more inclusive processes that engage with national and local actors to improve forest governance in ways that support, rather than criminalize, local forest use and conservation.

Funding Funding was provided by Swedish Research Council for Environment, Agricultural Sciences and Spatial Planning (Formas) through the research project "Effective and Equitable Institutional Arrangements for Financing and Safeguarding Biodiversity (Grant No. 254-2013-130)", and European Union's 7th Framework Program for Research (FP-7) INTEGRAL project (Grant No. FP7-282887).

Open Access This article is distributed under the terms of the Creative Commons Attribution 4.0 International License (http://creativecommons.org/licenses/by/4.0/), which permits unrestricted use, distribution, and reproduction in any medium, provided you give appropriate credit to the original author(s) and the source, provide a link to the Creative Commons license, and indicate if changes were made.

\section{Appendix}

\section{The Convention on Biological Diversity Voluntary Guidelines on Safeguards in Biodiversity Financ- ing Mechanisms (CBD 2014a)}

The Conference of the Parties of the Convention on Biological Diversity Decision 12 urges Parties, other Governments, business organizations and other stakeholders to take the voluntary guidelines on safeguards into account and urges Parties to consider undertaking, as appropriate, a review and assessment of existing legislation and policies governing biodiversity financing mechanisms:

" 15 . Adopts the voluntary guidelines on safeguards in biodiversity financing mechanisms, as contained in annex III to the present decision; 
16. Urges Parties, other Governments, business organizations and other stakeholders to take the voluntary guidelines on safeguards in biodiversity financing mechanisms into account when selecting, designing and implementing biodiversity financing mechanisms, and when developing instrument-specific safeguards for them, with a view to effectively harnessing their positive effects and avoiding or mitigating negative effects;

17. Urges Parties to consider undertaking, as appropriate, a review and assessment of existing legislation and policies governing biodiversity financing mechanisms, with a view to identifying opportunities for mainstreaming biodiversity and strengthening current policies and their complementary safeguards, and to make information on this work available to the Executive Secretary, including practical experiences and lessons learned;

18. Requests the Executive Secretary to compile a synthesis of the information provided by Parties pursuant to paragraph 17 above, for consideration by the Subsidiary Body for Implementation, at its first meeting" (UNEP/CBD/COP/DEC/XII/3)

\section{"VOLUNTARY GUIDELINES ON SAFEGUARDS IN BIODIVERSITY FINANCING MECHA- NISMS (CBD 2014a)}

(a) The role of biodiversity and ecosystem functions for local livelihoods and resilience, as well as biodiversity's intrinsic values, should be recognized in the selection, design and implementation of biodiversity financing mechanisms;

(b) Rights and responsibilities of actors and/or stakeholders in biodiversity financing mechanisms should be carefully defined, at national level, in a fair and equitable manner, with the effective participation of all actors concerned, including the prior informed consent or approval and involvement of indigenous and local communities, taking into account, the Convention on Biological Diversity and its relevant decisions, guidance and principles and, as appropriate, the United Nations Declaration of the Rights of Indigenous Peoples; ${ }^{\mathrm{a}}$

(c) Safeguards in biodiversity financing mechanisms should be grounded in local circumstances, be developed consistent with relevant country-driven/specific processes as well as national legislation and priorities, and take into account relevant international agreements, declarations and guidance, developed under the Convention on Biological Diversity and as appropriate, the United Nations Framework Convention on Climate Change, international human rights treaties and the United Nations Declaration of the Rights of Indigenous Peoples, among others;

(d) Appropriate and effective institutional frameworks are of utmost importance for safeguards to be operational and should be put in place, including enforcement and evaluation mechanisms that will ensure transparency and accountability, as well as compliance with relevant safeguards." (UNEP/CBD/COP/ DEC/XII/3, Annex III)

\section{EUTR Due Diligence System main elements}

Phase 1: Information: the operator must have access to a wide range of information concerning the timber that the operator wants to put on the internal market for the first time: description of the product, name (common and full scientific name of tree species, when the last is available), country of production, quantity, contact data of the operator's supplier(s) as well as of trader(s) to whom he procures timber, documents indicating compliance with the applicable legislation

Phase 2: Evaluation of the risk for the operator of placing illegal timber on the market, based on the timber product specific information gathered under phase 1) and on factors like certification or third-party verified schemes covering compliance with the applicable legislation, as well as information related to the context itself, like prevalence of illegal harvesting of the tree species, prevalence of illegal harvesting in the region of production, complexity of the supply chain, sanctions adopted by the United Nations or European Union

Phase 3: Risk reduction (if phase 2 shows that there is a non-negligible risk) through gathering of further information and/or third-party verification/certification

${ }^{\text {a }}$ General Assembly resolution 61/295 
List of Acronyms

\begin{tabular}{|c|c|}
\hline CBD & Convention on Biological Diversity \\
\hline CBD Addis Ababa Principles & $\begin{array}{l}\text { CBD Addis Ababa principles and guidelines for the sustainable use of } \\
\text { biodiversity }\end{array}$ \\
\hline CBD Akwé: Kon Guidelines & $\begin{array}{l}\text { Akwe: Kon voluntary guidelines for the conduct of cultural, environmen- } \\
\text { tal and social impact assessments regarding developments proposed } \\
\text { to take place on, or which are likely to impact on, sacred sites and on } \\
\text { lands and waters traditionally occupied or used by indigenous and local } \\
\text { communities }\end{array}$ \\
\hline CBD Guidelines for safeguards & $\begin{array}{l}\text { CBD voluntary guidelines for safeguards in biodiversity financing mecha- } \\
\text { nisms }\end{array}$ \\
\hline CAs & Competent Authorities \\
\hline CITES & $\begin{array}{l}\text { Convention on International Trade in Endangered Species of Wild Flora } \\
\text { and Fauna }\end{array}$ \\
\hline $\mathrm{COP}$ & Conference of the Parties \\
\hline DDS & Due Diligence System \\
\hline EUTR & EU Timber Regulation no. 995/2010 \\
\hline FAO & Food and Agriculture Organization \\
\hline FLEGT & EU Forest Law, Enforcement, Governance and Trade \\
\hline IPLCs & Indigenous peoples and local communities \\
\hline MO & Monitoring Organization \\
\hline REDD+ & $\begin{array}{l}\text { Reducing Emissions from Deforestation and Degradation and forest } \\
\text { enhancement }\end{array}$ \\
\hline SVLK & $\begin{array}{l}\text { Sistem Verificasi Legalitas Kayu is the acronym of Indonesia's national } \\
\text { timber legality assurance system }\end{array}$ \\
\hline UNFCCC & United Nations Framework Convention on Climate Change \\
\hline VPA & Voluntary Partnership Agreement \\
\hline WTO & World Trade Organization \\
\hline
\end{tabular}

\section{References}

Anton, D., \& Shelton, D. (2011). Procedural human rights and the environment. In environmental protection and human rights (pp. 356-435). Cambridge: Cambridge University Press. https://doi.org/10.1017/ CBO9780511974571.006.

Anton, D. K. (2012). "Treaty congestion" in international environmental law. In S. Alam, J. H. Bhuiyan, T. M. R. Chowdhury, \& E. J. Techera (Eds.), Routledge handbook of international environmental law (pp. 651-666). London: Routledge.

Bartley, T. (2014). Transnational governance and the re-centered state: Sustainability or legality? Regulation \& Governance, 8, 93-109.

Biermann, F., Pattberg, P., van Asselt, H., \& Zelli, F. (2009). The fragmentation of global governance architectures: A framework for analysis. Global Environmental Politics, 9(4), 14-40.

Bodin, B., Väänänen, E., \& van Asselt, H. (2015). Putting REDD+ environmental safeguards into practice: recommendations for effective and country-specific implementation. Carbon \& Climate L Rev, 9(168), $168-182$.

Brown Weiss, E. (1993). International environmental law: Contemporary issues and the emergence of a new world order. Georgetown Law Journal, 81(675), 675-710.

Bruch, C., Coker, W., \& Van Arsdale, C. (2001). Constitutional environmental law: Giving force to fundamental principles in Africa. Columbia Journal of Environmental Law, 26, 131-211. 
Carlarne, C. (2008). Good climate governance: Only a fragmented system of international law away? Law \& Policy, 30(4), 450-480.

CBD. (2008). Review of implementation of articles 20 and 21. UNEP/CBD/COP/DEC/IX/11. Montreal: Secretariat of the Convention on Biological Diversity.

CBD. (2014a). Resource mobilization and respective annex III. UNEP/CBD/COP/DEC/XII/3. Montreal: Secretariat of the Convention on Biological Diversity.

CBD. (2014b). Biodiversity and climate change and disaster risk reduction. UNEP/CBD/COP/DEC/XII/20. Montreal: Secretariat of the Convention on Biological Diversity.

CBD. (2018a). Comprehensive and participatory process for the preparation of the post-2020 global biodiversity framework. CBD/COP/DEC/14/34. Sharm El-Sheikh: Secretariat of the Convention on Biological Diversity.

CBD. (2018b). Safeguards in biodiversity financing mechanisms. CBD/COP/DEC/14/15. Sharm El- Sheikh: Secretariat of the Convention on Biological Diversity.

CBD. (2018c). Cooperation with other conventions, international organizations and initiatives. $\mathrm{CBD} / \mathrm{COP} /$ DEC/14/30. Sharm El-Sheikh: Secretariat of the Convention on Biological Diversity.

Ciparisse, G. (Ed.). (2003). Multilingual thesaurus on land tenure. Rome: Food and Agriculture Organization of the United Nations.

CITES. (2019a). Draft guidance for making legal acquisition findings. CITES-COP18 Doc. 39. Colombo: Secretariat of the Convention on International Trade in Endangered Species of Wild Fauna and Flora.

CITES. (2019b). Rosewood timber species (Leguminosae (Fabaceae)) CITES-COP18 Doc. 74. Colombo: Secretariat of the Convention on International Trade in Endangered Species of Wild Fauna and Flora.

Doelle, M. (2004). Linking the kyoto protocol and other multilateral environmental agreements: From fragmentation to integration? Journal of Environmental Law and Practice, 14, 75-104.

Ebbesson, J., \& Hey, E. (2013). Introduction: Where in law is social-ecological resilience? Ecology and Society, 18(3), 25.

EC. (2003). Forest law enforcement, governance and trade (FLEGT) proposal for an EU action plan. Brussels: European Commission.

EC. (2010). Regulation (EU) No 995/2010 of the European Parliament and of the Council of 20 October 2010 laying down the obligations of operators who place timber and timber products on the market. Text with EEA relevance. Brussels: European Commission.

Environmental Investigation Agency. (2017). The Rosewood Racket. https://eia-global.org/reports/the-rosew ood-racket. Accessed 17 March 2019.

Etty, T., Heyvaert, V., Carlarne, C., Farber, D., Lin, J., \& Scott, J. (2013). Norms, networks, and markets: navigating new frontiers in transnational environmental law. Transnational Environmental Law, 2(02), 203-210.

Geraets, D., \& Natens, B. (2015). Governing through trade in compliance with WTO law: A case study of the European Union Timber Regulation. In J. Woyters, A. Marx, D. Garaets, \& B. Natens (Eds.), Global governance through trade: EU policies and approaches (pp. 272-302). Cheltenham: Edward Elgar Publishing.

Ghezae, N., Berlekom, M., Engström, L., Eriksson, M. L., Gallardo, G., Gerhardt, K., et al. (2009). Natural resource tenure-A crucial aspect of poverty reduction and human rights. Sida Studies No. 23. Stockholm: Editia.

Hey, E. (2015). The interaction between human rights and the environment in the European 'Aarhus Space'. In A. Grear \& L. Kotzé (Eds.), Research handbook on human rights and the environment. Cheltenham: Edward Elgar Publishing.

Humphreys, D. (2008). Logjam: Deforestation and the crisis of global governance. London: Earthscan.

Ituarte-Lima, C., \& McDermott, C. (2017). Are more prescriptive laws better? Transforming REDD+ safeguards into national law. Journal of Environmental Law, 29(3), 505-536.

Ituarte-Lima, C., Schultz, M., Hahn, T., McDermott, C., Martinez-Peña, R., \& Cornell, S. (2018) CBD voluntary guidelines for safeguards: Implementation pathways. In Information document for the 14th conference of the parties for the convention on biological diversity, Sharm El-Sheikh, Egypt CBD/ $\mathrm{COP} / 14 / \mathrm{INF} / 37$.

Jonsson, R., Giurca, A., Masiero, M., Pepke, E., Pettenella, D., Prestemon, J.,et al. (2015). Assessment of the EU timber regulation and FLEGT action plan. From Science to Policy 1. European Forest Institute.

Knox, J. (2017). Report of the special rapporteur on the issue of human rights obligations relating to the enjoyment of a safe, clean, healthy and sustainable environment (A/HRC/34/49). Human Rights Council.

Knox, J., \& Boyd, D. (2018). Report of the special rapporteur on the issue of human rights obligations relating to the enjoyment of a safe, clean, healthy and sustainable environment. UN OHCHR (A/73/188) UN General Assembly. 
Larson, A. M., \& Ribot, J. (2007). The poverty of forestry policy: Double standards on an uneven playing field. Sustainability Science, 2, 189-204.

Lawson, S., \& MacFaul, L. (2010). Illegal logging and related trade. London: Chatham House. http:// www.illegal-logging.info/content/illegal-logging-and-related-trade-indicators-global-response?it_ id=938\&it=document. Accessed 3th January 2016.

Lesniewska, F., \& McDermott, C. L. (2014). FLEGT VPAs: Laying a pathway to sustainability via legality: Lessons from Ghana and Indonesia. Forest Policy and Economics, 48, 16-23.

Lyster, R., MacKenzie, C., \& McDermott, C. (Eds.). (2013). Law, tropical forests and carbon: The case of $R E D D+$. Cambridge: Cambridge University Press.

McDermott, C. L., Cashore, B., \& Kanowski, P. (2010). Global environmental forest policies: An international comparison. London: Earthscan.

McDermott, C. L., Hirons, M., \& Setyowati, A. (2019). The interplay of global governance with domestic and local access: Insights from the FLEGT VPAs in Ghana and Indonesia. Society and Natural Resources. https://doi.org/10.1080/08941920.2018.1544679.

McDermott, M., Mahanty, S., \& Schreckenberg, K. (2013). Examining equity: A multidimensional framework for assessing equity in payments for ecosystem services. Environmental Science \& Policy, 33, 416-427.

Obidzinski, K., Dermawan, A., Andrianto, A., Komarudin, H., Hernawan, D., \& Fripp, E. (2014). Timber legality verification system and the Voluntary Partnership Agreement in Indonesia: The challenges of the small-scale forestry sector. Working Paper 164. Bogor, Indonesia: CIFOR.

Overdevest, C., \& Zeitlin, J. (2014). Assembling an experimentalist regime: Transnational governance interactions in the forest sector. Regulation \& governance, 8, 1748-5991.

Savaresi, A. (2013) REDD+ and human rights: Addressing synergies between international regimes. Ecology and Society, 18(5), 5-13.

Savaresi, A. (2016). The legal status and role of REDD-plus safeguards. In C. Voigt (Ed.), Research handbook on REDD and international law. Cheltenham: Edward Elgar.

Schultz, M., Hahn, T., Ituarte-Lima, C., \& Hällström, N. (2018). Deliberative multi-actor dialogues as opportunities for transformative social learning and conflict resolution in international environmental negotiations. International Environmental Agreements: Politics, Law and Economics, 18(5), 671-688.

Scott, K. N. (2011). International environmental governance: Managing fragmentation through institutional connection. Melbourne Journal of International Law, 12(1), 177-216.

Setyowati, A., \& McDermott, C. L. (2017). Commodifying legality? Who and what counts as legal in the Indonesian wood trade. Society and Natural Resources, 30, 750-764.

Shelton, D. (1991). Human rights, environmental rights and the right to environment. Stanford Journal of International Law, 28, 103.

van Asselt, H. (2011). Legal and political approaches in interplay management: Dealing with the fragmentation of global climate governance. In S. Oberthür \& O. Stokke (Eds.), Interplay management in managing institutional complexity: Regime interplay and global environmental change (pp. 59-86). Cambridge: MIT Press.

van Asselt, H. (2012). Managing the fragmentation of international environmental law: Forests at the intersection of the climate and biodiversity regimes. New York University Journal of International Law and Politics, 44(4), 1205-1278.

van Asselt, H., Sindico, F., \& Mehling, M. A. (2008). Global climate change and the fragmentation of international law. Law \& Policy, 30(4), 423-449.

van Heeswijk, L., \& Turnhout, E. (2013). The discursive structure of FLEGT (Forest Law Enforcement, Governance and Trade): The negotiation and interpretation of legality in the EU and Indonesia. Forest Policy and Economics, 32, 6-13.

Voigt, C. (Ed.). (2016). Research handbook on REDD and international law. Cheltenham: Edward Elgar.

Voigt, C., \& Ferreira, F. (2015). The Warsaw framework for REDD+: Implications for national implementation and access to results-based finance. Carbon \& Climate Law Review, 9, 113.

Wolfrum, R., \& Matz, N. (2003). Conflicts in international environmental law. New York: Springer.

Publisher's Note Springer Nature remains neutral with regard to jurisdictional claims in published maps and institutional affiliations. 